Article

\title{
Seasonal Pattern of Decomposition and N, P, and C Dynamics in Leaf litter in a Mongolian Oak Forest and a Korean Pine Plantation
}

\author{
Jaeeun Sohng ${ }^{1,4}$, Ah Reum Han ${ }^{1}$, Mi-Ae Jeong ${ }^{1,5}$, Yunmi Park ${ }^{2}$, Byung Bae Park ${ }^{3}$ and \\ Pil Sun Park ${ }^{1, *}$
}

1 Department of Forest Sciences, Seoul National University, Seoul 151-921, Korea;

E-Mails: jaeeun.sohng@yale.edu (J.S.); phoya@naver.com (A.R.H); sangdi@snu.ac.kr (M.-A.J)

2 Division of Special-purpose Trees, Korea Forest Research Institute, Suwon 441-847, Korea;

E-Mail: pym5250@hanmail.net

3 Department of Environment and Forest Resources, Chungnam National University, Daejeon 305-764, Korea; E-Mail: bbpark@cnu.ac.kr

4 School of Forestry \& Environmental Studies, Yale University, New Haven, CT 06511, USA

5 Department of Landscape Architecture, Seoul National University, Seoul 151-921, Korea

* Author to whom correspondence should be addressed; E-Mail: pspark@snu.ac.kr;

Tel.: +82-2-880-4771; Fax: +82-2-873-3560.

External Editor: Heinz Rennenberg

Received: 22 August 2014; in revised form: 17 October 2014 / Accepted: 17 October 2014 /

Published: 23 October 2014

\begin{abstract}
Distinct seasons and diverse tree species characterize temperate deciduous forests in NE Asia, but large areas of deciduous forests have been converted to conifer plantations. This study was conducted to understand the effects of seasons and tree species on leaf litter decomposition in a temperate forest. Using the litterbag method, the decomposition rate and nitrogen, phosphorous, and carbon dynamics of Mongolian oak (Quercus mongolica), Korean pine (Pinus koraiensis), and their mixed leaf litter were compared for 24 months in a Mongolian oak stand, an adjacent Korean pine plantation, and a Mongolian oak-Korean pine mixed stand. The decomposition rates of all the leaf litter types followed a pattern of distinct seasonal changes: most leaf litter decomposition occurred during the summer. Tree species was less influential on the leaf litter decomposition. The decomposition rates among different leaf litter types within the same stand were not significantly different, indicating no mixed litter effect. The immobilization of leaf litter $\mathrm{N}$ and $\mathrm{P}$ lasted for 14 months. Mongolian
\end{abstract}


oak leaf litter and Korean pine leaf litter showed different $\mathrm{N}$ and $\mathrm{P}$ contents and dynamics during the decomposition, and soil $\mathrm{P}_{2} \mathrm{O}_{5}$ was highest in the Korean pine plantation, suggesting effects of plantation on soil nutrient budget.

Keywords: temperate deciduous forest; mixed leaf litter effect; soil nutrients; leaf litter nutrients; mineralization

\section{Introduction}

Leaf litter decomposition is a critical step in nutrient cycling and providing nutrients to plants [1]. Various factors control leaf litter decomposition, including climate [2], topography [3,4], chemical characteristics of leaf litter [5,6], and terrestrial microbiota [7]. Among those factors, climate, especially temperature and precipitation, is a dominant factor determining leaf litter decomposition patterns in regions experiencing distinct seasonal climate change [8].

Every ecosystem has its own physical characteristics and specific environment that foster the distinct features of its species composition. Each tree species affects leaf litter decomposition differently by providing leaf litters of different quality, which are closely related to the terrestrial microbial community and soil nutrient cycling $[9,10]$. In temperate natural forests, plant leaf litter usually decomposes in a mixed-species environment. Mixedwood forests are characterized by diverse soil conditions and biological activity within short distances, increasing the importance of small-spatial-scale research on soil nutrient pools, as well as integrating diverse chemical variables of single or mixed species into different temporal and spatial scales [6,11]. However, species composition is one of the factors most altered by human activities as natural mixedwood forests have been converted to single-species plantations. Stand conversion from natural forest to single species plantation changes leaf litter decomposition and eventually alters ecosystem functions [12].

Information on the nutrient cycling within plantations, such as patterns of $\mathrm{N}, \mathrm{P}$, and $\mathrm{C}$ release, immobilization and mineralization in a decomposing phase, and the planted species' interactions with existing species, is crucial to properly manage plantations and improve their vitality to be similar to natural states [13]. However, limited information is available on the effects of a plantation on nutrient cycling at a site and on plantation interactions with existing ecosystems [14]. Thus, an increasing number of studies investigate the effect of certain species on the decomposition of single or mixed leaf litters for better plantation management or restoration of natural stands $[15,16]$. Those studies simultaneously integrate features of species, mixed leaf litters, and forest floor conditions by forest type to explain the leaf litter decomposition process [17,18].

Korean pine (Pinus koraiensis Siebold et Zucc.) is a representative species in northern temperate old-growth forests and has been widely planted for wood and pine seeds in NE Asia [19,20]. The total plantation area of Korean pine in South Korea is $c a$. 214,357 ha, making Korean pine the third most planted species in Korea [20]. Most Korean pine plantations replace oak-dominant broadleaved stands and are still adjacent to broadleaved forests dominated by oak species such as the oriental cork oak (Quercus variabilis Blume), konara oak (Quercus serrata Thunb.), and Mongolian oak. The 
establishment of Korean pine plantations might alter leaf litter decomposition patterns and affect the nutrient budget of an area.

This study compared leaf litter decomposition characteristics and nutrient dynamics between an oak-dominant secondary deciduous stand and a Korean pine plantation to understand the plantation effect on nutrient cycling. We hypothesized that different leaf litter types would show different leaf litter decomposition rates and nitrogen $(\mathrm{N})$, phosphorous $(\mathrm{P})$, and carbon $(\mathrm{C})$ mineralization patterns by forest type. We expected nutrient transport between the Mongolian oak leaf litter and the Korean pine leaf litter to induce complementary interactions, resulting in a synergistic effect that would give the mixed leaf litter the highest decomposition rate.

Efforts to introduce mixedwood forests that are more ecologically sound and resistant to disturbances than monoculture are increasing in NE Asia [21]. Understanding the leaf litter decomposition process in Korean pine plantations would show what happens when a plantation replaces a natural stand and how a plantation interacts with existing ecosystems.

\section{Materials and Methods}

\subsection{Study Sites}

The study was conducted at three types of stands in the Seoul National University Forest at

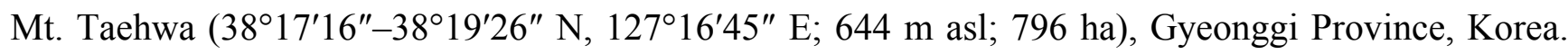
The area is a temperate zone with a continental monsoon climate. The annual mean precipitation in this area is $1371 \mathrm{~mm}$ with about sixty percent of the annual precipitation is concentrated between June and August [22]. Meteorological data from the weather station of the University Forest during 2009-2011 showed that the annual mean air temperature was $10.9{ }^{\circ} \mathrm{C}$, with a maximum temperature of $33.5^{\circ} \mathrm{C}$ in July and a minimum temperature of $-21.3{ }^{\circ} \mathrm{C}$ in January. It was relatively dry in the winter, with precipitation of $90 \mathrm{~mm}$ in the form of snow from December 2010 to February 2011. Snow depth at the study sites ranged from 5 to $20 \mathrm{~cm}$ depending on the slope aspect. Soils in the forest are classified as coarse loamy, in the mesic family of Typic Dystrudepts according to the USDA soil classification system [23]. Soil parent material was an eluvium of metamorphic rock, such as biotite and granite gneiss. The depth of the leaf litter layer ranged 3-7 cm in native secondary forests and 2-6 cm in Korean pine plantations in both spring and autumn.

Mt. Taehwa belongs to a broadleaved deciduous forest zone; however, most of the lower slopes are covered by Korean pine and Japanese larch (Larix kaempferi (Lamb.) Carrière) plantations. The Korean pine plantations in Mt. Taehwa occupied 136 ha and most of them were established in late 1960s. Because the Korean pine plantations were established in a relatively short period of time and distributed on lower slopes that had similar soil condition, they had a similar stand structure. Secondary natural stands, occupying 497 ha, were distributed on the upper slopes and ridges and were dominated by oaks, such as Mongolian oak, oriental cork oak, and oriental white oak (Quercus aliena Blume).

Three types of stands were selected: a secondary natural stand dominated by Mongolian oak (hereafter called oak stand), an adjacent Korean pine plantation (5.5 ha) established in 1969, and a Korean pine-Mongolian oak mixed stand (hereafter called mixed stand). The mixed stand was located between the oak stand and the Korean pine plantation and was established as a Korean pine plantation. However, 
Mongolian oak from the adjacent natural stands invaded the plantation and replaced part of the Korean pine. The Mongolian oak in the oak stand and the Korean pine in the Korean pine plantation occupied $79.1 \%$ and $97.6 \%$ of each stand's basal area, respectively. The respective basal areas within the mixed stand were 48.4\% Korean pine and 39\% Mongolian oak. All study sites were at an altitude of 229-285 $\mathrm{m}$ asl, and the slope steepness was 36-67\%. The oak stand was on a NW slope and the mixed stand on a NE slope. The Korean pine plantation grew across different oriented slopes from $120-315^{\circ}$; however, it mostly faced south (Table 1 ).

In each type of stand, three $20 \mathrm{~m} \times 20 \mathrm{~m}$ plots were randomly established. All trees $\geq 2.5 \mathrm{~cm}$ in diameter at breast height (DBH; $1.3 \mathrm{~m}$ above the ground) were measured within each $20 \mathrm{~m} \times 20 \mathrm{~m}$ plot. For each tree, species names, DBH, tree condition (alive, dead, broken top, or leaning), crown width, and proportion of crown to tree height were recorded.

Table 1. Selected characteristics of the three study sites in the Seoul National University Forest at Mt. Taehwa, Gyeonggi Province.

\begin{tabular}{cccc}
\hline Stand types & Oak stand & Mixed stand & Korean pine plantation \\
\hline Altitude $(\mathrm{m})$ & $284-285$ & $258-270$ & $229-239$ \\
Slope steepness $(\%)$ & $43-67$ & $36-47$ & $42-55$ \\
Aspect $\left(^{\circ}\right)$ & $315-335$ & $36-47$ & $120-315$ \\
Soil texture & Loam & Loam & Loam \\
Sand (\%) & 38 & 36 & 36 \\
Silt (\%) & 39 & 41 & 41 \\
Clay (\%) & 23 & 23 & 23 \\
& Quercus mongolica & & \\
Species (density & $(567,79.1)$, Pinus & P. koraiensis $(425,48.4)$, & P. koraiensis $(725,97.6)$, \\
$($ number of & koraiensis (308, 7.9), & Q. mongolica $(256,39)$, & Q. variabilis $(17,1.0)$, \\
stems ha $\left.{ }^{-1}\right)$, relative & Kalopanax septemlobus & Q. variabilis $(25,3.7)$, & Styrax obassia $(42,0.7)$, \\
basal area $(\%))$ & $(17,2.9)$, Others & Others $(127,8.9)$ & Others $(50,0.7)$ \\
& $(767,10.1)$ & & \\
\hline
\end{tabular}

\subsection{Soil Measurements, Sampling, and Analysis}

A HOBO soil data logger (HOBO H21-002 Micro Station, On-set computer Corporation, USA) was installed in the center of each study site. The soil temperature $\left({ }^{\circ} \mathrm{C}\right)$ and soil moisture content $\left(\mathrm{m}^{3} \mathrm{~m}^{-3}\right)$ were measured from 28 March 2010 to 31 March 2011 at 30-minute intervals at $10 \mathrm{~cm}$ soil depth. The daily mean soil temperature and daily mean soil water content were calculated.

Soil samples were collected from the soil surface to a depth of $10 \mathrm{~cm}$ with a soil sampling container $\left(100 \mathrm{~cm}^{3}\right)$ from all the plots in March, June, and October 2010. At each plot, four sampling points were randomly selected $1.5-2 \mathrm{~m}$ from the base of a tree trunk to minimize the direct physical and chemical influences of roots [4]. A total of 36 soil samples at a time were collected from the three stand types. The soils were oven-dried at $105{ }^{\circ} \mathrm{C}$ for 24 hours and the soil water content (\%) was measured on a gravimetric basis. A particle-size analysis was conducted with the pipette method [24], and soil texture (standard of US Department of Agriculture) was determined. We measured soil organic matter contents by combusting it at $600{ }^{\circ} \mathrm{C}$ for 4 hours in a muffle furnace and weighing the residue [25]. For chemical 
analyses, the sampled soils were air-dried and sieved $(<2 \mathrm{~mm})$. We measured soil $\mathrm{pH}$ (soil:water $=1: 5)$, total nitrogen content (TN) [25], cation exchange capacity (CEC) [26], and total phosphorus (TP; inductively coupled plasma ICPS-1000IV, Shimazu, Japan). Available soil phosphorous $\left(\mathrm{P}_{2} \mathrm{O}_{5}\right)$ was determined by analyzing the Bray No. 1 extracts with an ICP (inductively coupled plasma) optical emission spectrometer (ICP-730 ES, Varian, USA). We used an elemental analyzer to measure the C:N ratio (Flash EA 1112, Thermo Electron Corporation, USA).

\subsection{Leaf litter Decomposition Experiment}

Leaf litter fall of Mongolian oak and Korean pine (5-6 kg per each species) was collected from forest floor of the Mongolian oak stand and Korean pine plantation, respectively, in the study sites in March 2009. Our study focused on in-situ condition and year-round changes in leaf litter on the forest floor. Leaf litter fall of Mongolian oak occurred in autumn and Korean pine was a conifer with leaf litter fall distributed over the whole year, so we collected forest floor litter in March before active decomposition began instead of autumn to avoid the combination of very fresh Mongolian oak litter fall and relatively less fresh Korean pine litter fall. We were careful to collect intact leaves without clear sign of decomposition from the top layer. The leaf litter sample was oven-dried at $80^{\circ} \mathrm{C}$ for 48 hours. The oven-dried leaf litter was weighed into $10 \mathrm{~g}$ samples and put into litterbags, either pure or in a 1:1 ratio of the two leaf litters by mass [27,28]. Each litterbag was $20 \mathrm{~cm} \times 10 \mathrm{~cm}$ and was made of nylon mesh $(1 \mathrm{~mm} \times 1.2 \mathrm{~mm}$ mesh size).

The litterbags were placed on topsoil parallel to the forest floor in each study plot in April 2009. A total of 972 litterbags were deployed at the study sites: 3 stand types $\times 3$ plots at each stand type $\times 3$ leaf litter types $\times 3$ replicates $\times 12$ retrieving dates from April 2009 to March 2011. Each litterbag was at least $15 \mathrm{~cm}$ away from other litterbags, and all litterbags at each site were tied together with a nylon string to minimize unnecessary movements. Every two months, 27 litterbags were retrieved from each study site. The retrieved leaf litter was oven-dried at $80{ }^{\circ} \mathrm{C}$ for 48 hours and brushed carefully to minimize soil contamination [29]. Oven-dried litter was weighed to the nearest $0.01 \mathrm{~g}$ to determine its mass loss, and milled for chemical analyses [30]. Total nitrogen and $\mathrm{C}$ concentrations $\left(\mathrm{mg} \mathrm{g}^{-1}\right)$ were measured using a dry combustion method with a C-N analyzer (Yanaco MT-500, Kyoto, Japan) [28]. Total P in the leaf litter was determined with an automated ion analyzer (QuikChem AE, Lachat Inc., Loveland, Colorado, USA). The amount of nutrients in the leaf litter was calculated as follows:

$$
N_{t}=\frac{C_{t}}{100} \times L_{t}
$$

Where $N_{\mathrm{t}}$ is the amount of nutrient $(\mathrm{g})$ at time $t, C_{\mathrm{t}}$ is the percent concentration of nutrient at time $t$, and $L_{\mathrm{t}}$ is the leaf litter remaining mass $(\mathrm{g})$ at time $t$.

\subsection{Data Analysis}

The decomposition rate constant $(\mathrm{k})$ was derived from the negative exponential decomposition equation proposed by Olson [31] as follows:

$$
-\mathrm{k}=\ln \left(\frac{\mathrm{X}}{\mathrm{X}_{0}}\right) t
$$

Where $X_{0}$ is the initial mass, and $X$ is the remaining mass at time $t$. 
The predicted remaining mass for the mixed leaf litter was estimated using equation (3) based on the observed remaining mass of the single species to verify a mixed effect on leaf litter decomposition [29]. The predicted results were compared with the observed remaining mass of the mixed leaf litter.

$$
E_{\mathrm{ML}}=\sum_{i=1}^{\mathrm{S}} O_{\mathrm{ML} i} \times P_{\mathrm{IM} i}
$$

Where $E_{\mathrm{ML}}$ is the predicted remaining mass of mixed litter (\%); $S$ is the species; $O_{\mathrm{MLi}}$ is the observed leaf litter mass of the single species (\%); and $P_{\mathrm{IM} i}$ is the initial proportion of species $i$.

When the observed remaining mass of mixed leaf litter is not significantly different from the predicted results, mixing has an additive effect; otherwise, it has a non-additive effect. The non-additive effect is differentiated into a synergistic effect (decomposition rates are more than predicted values) or an antagonistic effect (decomposition rates are less than predicted values) [16]. The predicted and observed remaining mass were compared using a paired t-test to determine possible mixed leaf litter effects (i.e., additive or non-additive).

One-way ANOVA was used to compare the decomposition rate constant $(k)$ and the changes in leaf litter $\mathrm{N}, \mathrm{P}$, and $\mathrm{C}$ concentrations among the three stand types. A simple linear regression was used to assess the relationship between mass loss (\%) and total $\mathrm{C}$ in decomposing leaf litters. The relationship between the total N, P, and C in each leaf litter type over 24 months was estimated using polynomial regression analysis.

A repeated-measures ANOVA was used to compare the soil physical and chemical characteristics in different seasons (March, June, and October 2010) and identify whether significant differences occurred in mass loss and changes in leaf litter $\mathrm{N}$ and $\mathrm{P}$ every two months by leaf litter type in a single stand or among the stand types. Tukey's test was applied for post-hoc comparisons, with significance set at $p<0.05$. The SPSS statistical package program Version 18.0 was used for all statistical analyses (SPSS Software 2009, IBM SPSS Inc., Chicago, IL, USA).

\section{Results}

\subsection{Soil Characteristics}

All study sites had similar soil temperatures. The maximum soil temperature reached at $24{ }^{\circ} \mathrm{C}$ in August, and it stayed near $0{ }^{\circ} \mathrm{C}$ in January and February (Figure 1). The Korean pine plantation had a daily mean soil moisture content lower than the other two stand types in June, October, and November (Figure 1), and soil moisture content measurements lower than the other two stand types in March and October 2010 (Table 2; $p<0.001$ ). All study sites showed similar daily soil moisture content in the summer.

The three stand types showed significant differences in soil TN concentrations, which were highest in the oak stand and lowest in the Korean pine plantation in spring and autumn $(p=0.03)$. However, soil $\mathrm{TN}$ did not significantly differ among stand types in the summer. The oak stand had the highest organic matter content $(19.7 \%)$ in March $2010(p<0.05)$, but we found no differences in organic matter content in the summer and autumn (Table 2). 
Figure 1. Daily mean soil temperatures $\left(\mathrm{St},{ }^{\circ} \mathrm{C}\right)$ and daily mean soil water contents $\left(\mathrm{Sw}, \mathrm{m}^{3} \mathrm{~m}^{-3}\right)$ of the Mongolian oak stand, the mixed stand, and the Korean pine plantation from 28 March 2010 to 31 March 2011.

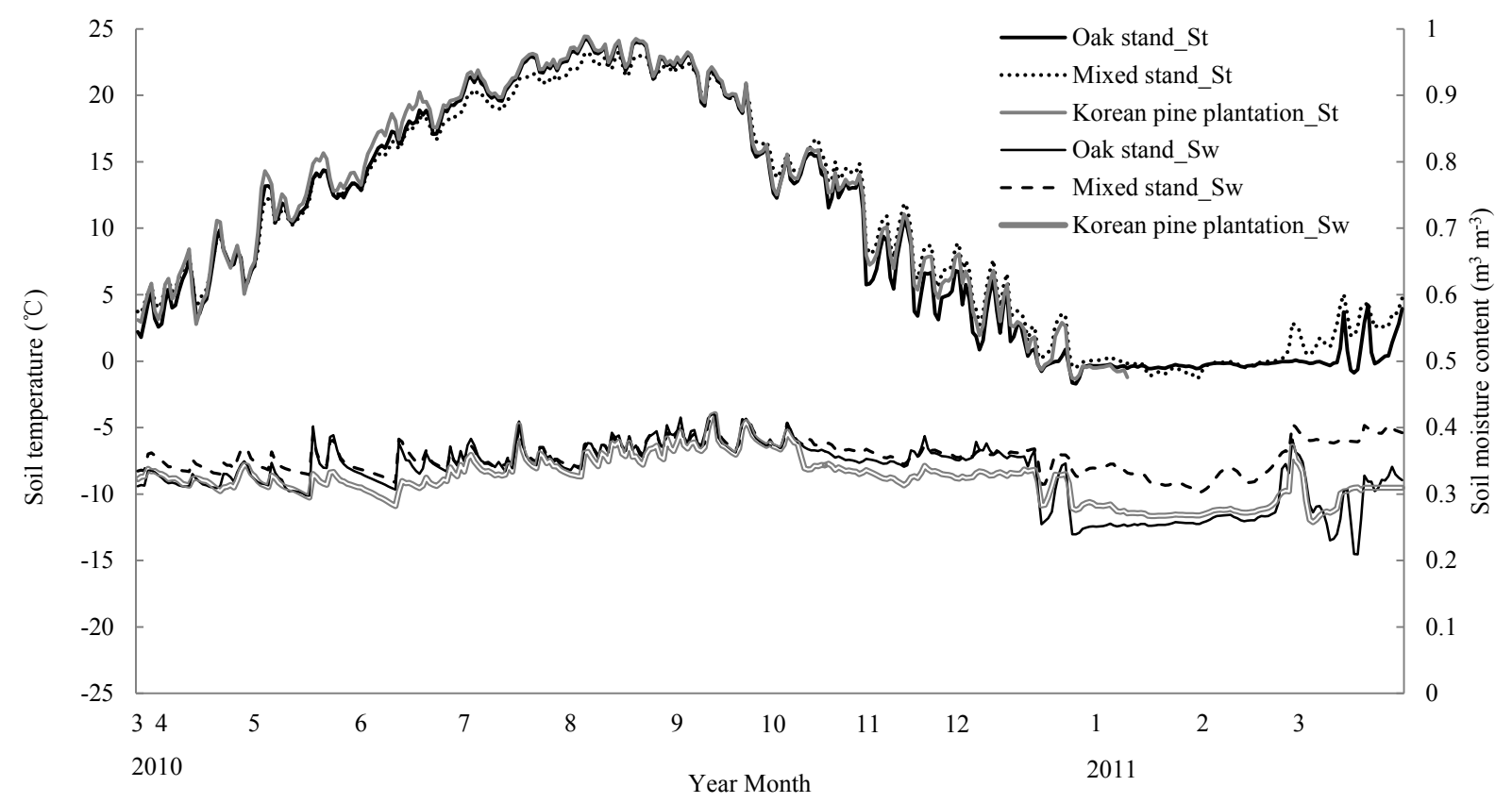

The soil $\mathrm{P}_{2} \mathrm{O}_{5}$ content was highest in the Korean pine plantation with $126.7 \mathrm{mg} \mathrm{L}^{-1}$; was more than twice the $49 \mathrm{mg} \mathrm{L}^{-1}$ observed in the oak stand in March 2010. The largest soil N:P ratio was therefore in the oak stand (Figure 2), which had the lowest soil $\mathrm{P}_{2} \mathrm{O}_{5}$ and substantial seasonal differences in soil $\mathrm{P}_{2} \mathrm{O}_{5}$ and soil N:P $(p=0.015)$ between March and October, 2010, though few seasonal changes in soil TN were observed. Due to the high variability of soil $\mathrm{P}_{2} \mathrm{O}_{5}$ within the stands, soil $\mathrm{P}_{2} \mathrm{O}_{5}$ contents among the stands were not significantly different. Soil pH, TP, and CEC were not significantly different among the stand types.

Figure 2. Seasonal changes in the soil N:P ratio in soil $(0-10 \mathrm{~cm})$ at the study sites. Data are means $\pm \mathrm{SE}(n=9)$. Data in the same stand followed by the different letters are significantly different at $p<0.05$ according to $t$-tests.

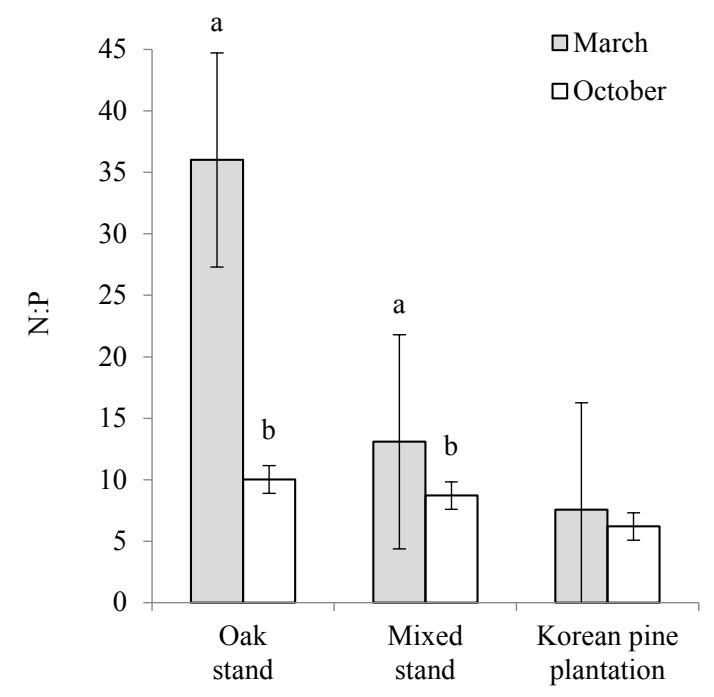


Table 2. Soil chemical characteristics of the three study sites in the Seoul National University Forest at Mt. Taehwa, Gyeonggi Province in March, June, and October 2010.

\begin{tabular}{|c|c|c|c|c|c|c|c|c|c|}
\hline Month & Stand type & $\begin{array}{c}\text { Soil water } \\
\text { content }(\%)\end{array}$ & $\begin{array}{c}\text { Organic } \\
\text { matter }(\%)\end{array}$ & pH & Total N (\%) & $\begin{array}{c}\text { Total P } \\
\left(\mathrm{mg} \mathrm{L}^{-1}\right)\end{array}$ & $\begin{array}{c}\mathbf{P}_{2} \mathrm{O}_{5} \\
\left(\mathrm{mg} \mathrm{L}^{-1}\right)\end{array}$ & $\begin{array}{c}\text { CEC } \\
\left(\mathrm{cmol} \mathrm{kg}^{-1}\right)\end{array}$ & $\mathrm{C}: \mathrm{N}$ ratio \\
\hline \multirow{3}{*}{ March } & Oak stand & $67.3 \pm 11.5^{\mathrm{a}}$ & $19.7 \pm 2.8^{\mathrm{a}}$ & $4.0 \pm 0.2$ & $0.60 \pm 0.00^{\mathrm{a}}$ & $301.2 \pm 12.8$ & $49.0 \pm 7.7$ & $23.0 \pm 0.8$ & $14.6 \pm 0.2^{\mathrm{ab}}$ \\
\hline & Mixed stand & $53.4 \pm 6.4^{b}$ & $16.2 \pm 2.1^{b}$ & $4.0 \pm 0.1$ & $0.43 \pm 0.02^{b}$ & $308.5 \pm 15.6$ & $97.9 \pm 20.1$ & $21.4 \pm 1.4$ & $14.0 \pm 0.0^{b}$ \\
\hline & $\begin{array}{c}\text { Korean pine } \\
\text { plantation }\end{array}$ & $42.7 \pm 5.8^{c}$ & $13.3 \pm 2.7^{\mathrm{c}}$ & $4.3 \pm 0.9$ & $0.30 \pm 0.03^{c}$ & $278.1 \pm 43.7$ & $126.7 \pm 34.2$ & $18.6 \pm 4.2$ & $15.0 \pm 0.3^{\mathrm{a}}$ \\
\hline \multirow{3}{*}{ June } & Oak stand & - & - & - & $0.44 \pm 0.04$ & $248.5 \pm 16.8$ & $60.2 \pm 5.2$ & - & $15.0 \pm 0.6^{\mathrm{ab}}$ \\
\hline & Mixed stand & - & - & - & $0.36 \pm 0.02$ & $269.1 \pm 21.0$ & $79.8 \pm 12.1$ & - & $13.8 \pm 0.3^{b}$ \\
\hline & $\begin{array}{c}\text { Korean pine } \\
\text { plantation }\end{array}$ & - & - & - & $0.30 \pm 0.05$ & $238.3 \pm 45.1$ & $73.0 \pm 20.0$ & - & $16.1 \pm 0.5^{\mathrm{a}}$ \\
\hline \multirow{3}{*}{ October } & Oak stand & $60.4 \pm 7.1^{\mathrm{a}}$ & $16.6 \pm 3.0$ & $4.1 \pm 0.3$ & $0.50 \pm 0.03^{\mathrm{a}}$ & $315.1 \pm 19.3$ & $129.9 \pm 14.2$ & - & $14.0 \pm 0.2^{b}$ \\
\hline & Mixed stand & $49.3 \pm 8.1^{b}$ & $14.4 \pm 2.0$ & $4.0 \pm 0.1$ & $0.47 \pm 0.02^{\mathrm{a}}$ & $337.3 \pm 18.7$ & $129.4 \pm 7.1$ & - & $15.4 \pm 0.4^{\mathrm{a}}$ \\
\hline & $\begin{array}{c}\text { Korean pine } \\
\text { plantation }\end{array}$ & $39.6 \pm 7.0^{c}$ & $13.8 \pm 4.4$ & $4.1 \pm 0.1$ & $0.30 \pm 0.05^{b}$ & $296.1 \pm 53.0$ & $143.4 \pm 99.6$ & - & $15.8 \pm 0.3^{a}$ \\
\hline
\end{tabular}

Data in the same month followed by the same letter are not significantly different at $p<0.05$ according to Tukey’s multiple range tests; Values are means \pm SE. 


\subsection{Leaf litter Decomposition and Mixed Leaf litter Effects}

All leaf litter showed distinct seasonal changes in decomposition rates. About $20 \%$ of mass loss occurred in all study sites during the initial six months from April to October 2010 regardless of leaf litter type. Little change in the remaining mass was detected in the subsequent six months (during winter and spring). During the second summer, fourteen months after the experiment started, all types of leaf litter in each stand lost $14 \%-29 \%$ of the original mass (Figure 3).

The leaf litter decomposition rate in the oak stand was significantly slower than those in the Korean pine plantation and the mixed stand until the second summer $(p<0.001)$. The leaf litter decomposition rate was highest in the Korean pine plantation and lowest in the oak stand for 17 months. Although the leaf litter mass loss in the oak stand was less than that in the other stands prior to the second summer, the remaining leaf litter mass continuously decreased in the oak stand during the second autumn, whereas further decomposition did not progress in the other stands.

As a result, after 24 months the remaining leaf litter mass was similar among the stand types, ranging from approximately $41-47 \%$. No significant difference was found in the decomposition rate among the leaf litter types in the same stand.

Figure 3. Percent remaining leaf litter mass for Mongolian oak leaf litter (black solid line), Korean pine leaf litter (gray solid line) and mixed leaf litter (dashed line) in (A) the oak stand, (B) the mixed stand, and (C) the Korean pine plantation. Data are means $\pm \mathrm{SE}(n=9)$.
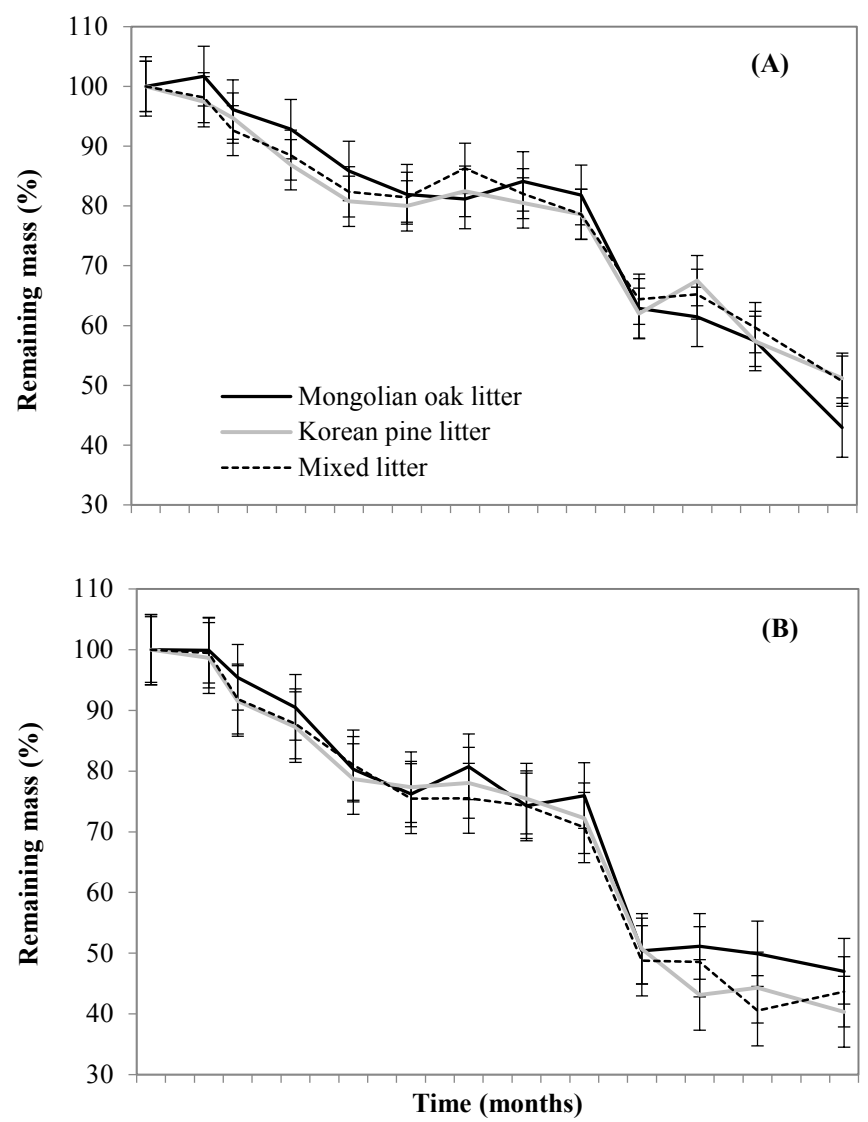
Figure 3. Cont.

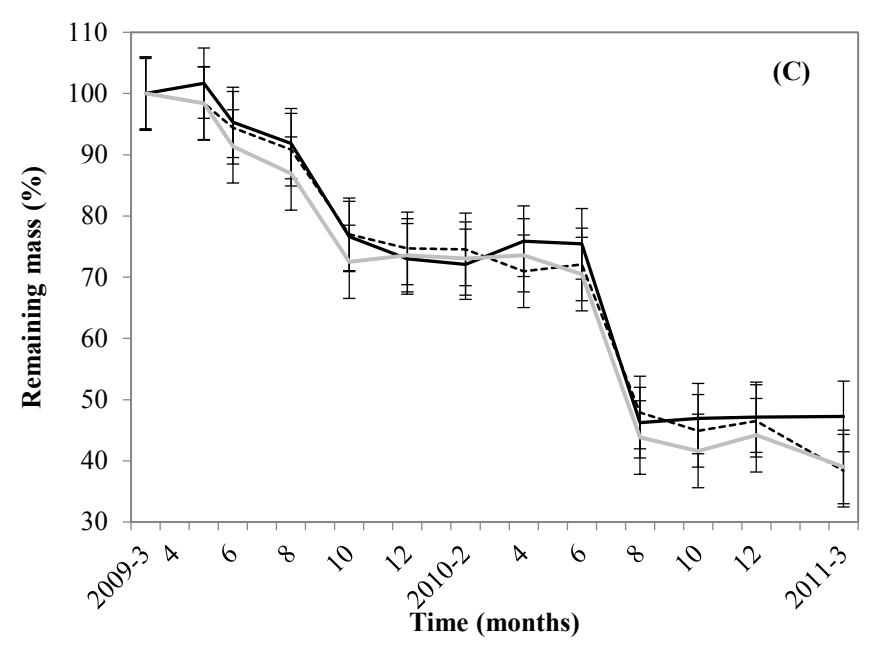

Observed and predicted decay constants in each stand were not significantly different, indicating that the leaf litter mixing of Korean pine and Mongolian oak had an additive effect on leaf litter decomposition. We found no significant synergistic or antagonistic interactions between those two species in leaf litter decomposition over 24 months (Figure 4).

Figure 4. Comparisons of predicted (white bars) and observed (grey bars) decay constant $k$ at each site. Predicted values calculated from the corresponding monoculture litterbags (paired $t$ - test). Data are means $\pm \mathrm{SE}(n=9)$.

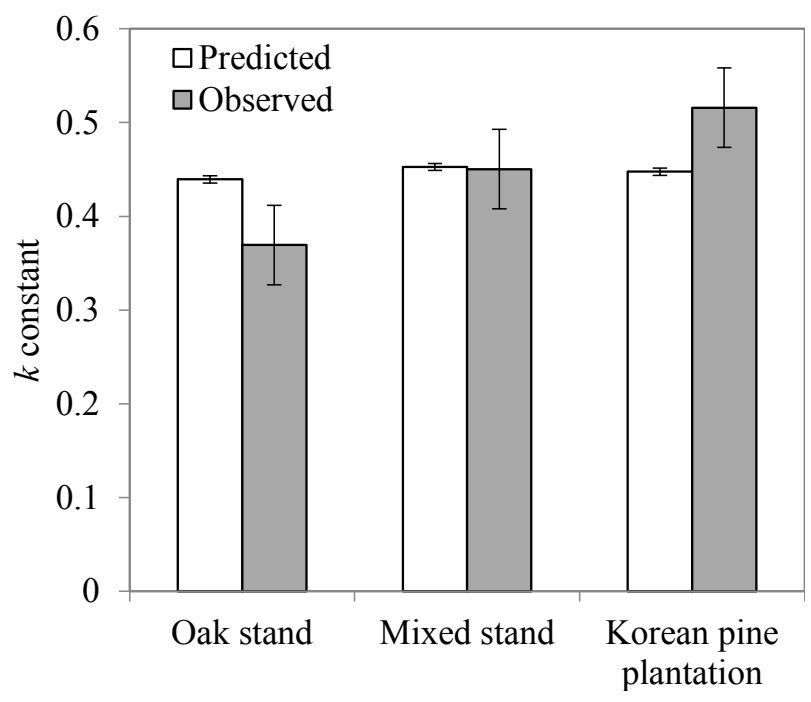

\subsection{Leaf litter $N, P$, and C Changes and Relationships}

Changes in the decomposition constant $(k)$ for 24 months corresponded to changes in the amount of $\mathrm{C}$ in decomposing leaf litters, and those changes were highly correlated $(p<0.001$; Table 3 ). The amount of leaf litter $\mathrm{C}$ decreased in a pattern similar to leaf litter mass loss (Figure 3 ). Consequently, the changes in leaf litter $\mathrm{C}$ mass did not vary among leaf litter types, but they were significantly different among stands: the oak stand retained significantly more leaf litter $\mathrm{C}$ than the other stands $(p<0.001)$. 
Table 3. Leaf litter decomposition constant $(k)$ and $\mathrm{C}$ percentage after 24 months relative to the initial leaf litter C $(n=9)$, and $R^{2}$-values of simple linear regression for the relationship between mass loss $(\%)$ and leaf litter $\mathrm{C}$ in the decomposing phase $(p<0.05)$.

\begin{tabular}{ccccccc}
\hline Forest type & Leaf litter type & $\boldsymbol{k}$ & $\mathbf{C ~ ( \% )}$ & Regression & $\boldsymbol{R}^{\mathbf{2}}$ \\
\hline Oak stand *** & Mongolian oak & 0.4588 & 34.0 & $\mathrm{C}=-0.0935 x+7.8699$ & 0.86 \\
& Mixed leaf litter & 0.3694 & 32.5 & $\mathrm{C}=-0.0934 x+7.9997$ & 0.72 \\
& Korean pine & 0.3774 & 33.1 & $\mathrm{C}=-0.0927 x+8.1664$ & 0.87 \\
Mixed stand & Mongolian oak & 0.4035 & 29.7 & $\mathrm{C}=-0.0921 x+7.9344$ & 0.88 \\
& Mixed leaf litter & 0.4504 & 28.3 & $\mathrm{C}=-0.0902 x+8.1363$ & 0.98 \\
Korean pine & Korean pine & 0.4886 & 25.2 & $\mathrm{C}=-0.1045 x+8.4264$ & 0.93 \\
plantation & Mongolian oak & 0.4056 & 25.1 & $\mathrm{C}=-0.0894 x+7.9403$ & 0.97 \\
& Mixed leaf litter & 0.5159 & 23.1 & $\mathrm{C}=-0.0875 x+7.9612$ & 0.92 \\
\hline
\end{tabular}

The notation $* * *$ indicates that the leaf litter $\mathrm{C}$ percentage among the forest types after 24 months is significantly different at $p<0.001$.

Percentage changes in leaf litter $\mathrm{N}$ and $\mathrm{P}$ showed that $\mathrm{N}$ and $\mathrm{P}$ were immobilized during the first year in all study sites. The immobilization was sustained until the beginning of the second summer, June 2010. Mineralization of $\mathrm{N}$ and $\mathrm{P}$ was observed after 14 months (Figure 5).

Figure 5. Percent of original $N((\mathbf{A}),(\mathbf{B})$ and $(\mathbf{C}))$ and $P((\mathbf{D}),(\mathbf{E})$ and $(\mathbf{F}))$ remaining for Mongolian oak leaf litter (black solid line), Korean pine leaf litter (gray solid line) and mixed leaf litter (dashed line) during the decomposition in (A), (D) the oak stand, (B), (E) the mixed stand, and $(\mathbf{C}),(\mathbf{F})$ the Korean pine plantation after 24 months. Data are means $\pm \operatorname{SE}(n=9)$.
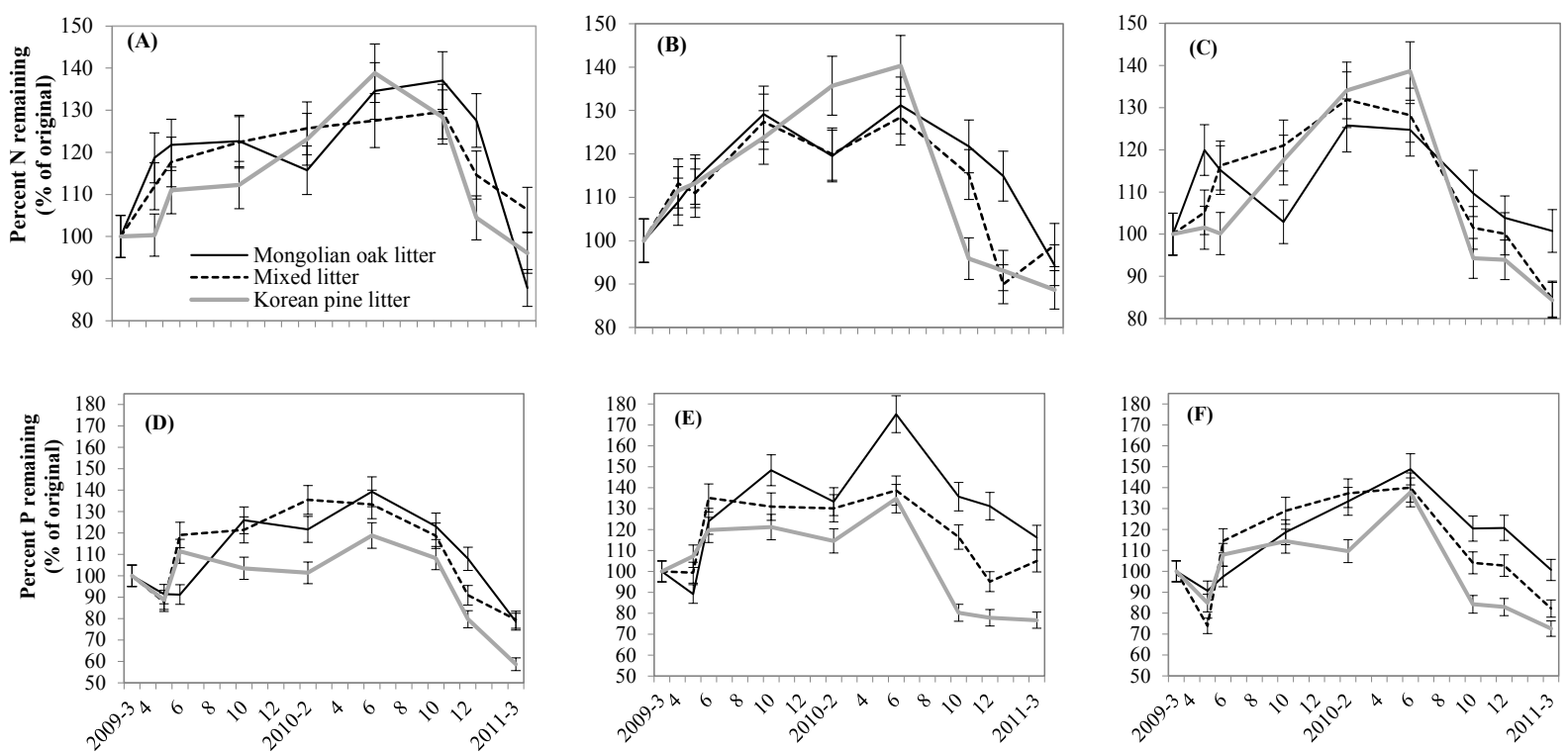

The shift from $\mathrm{N}$ immobilization to $\mathrm{N}$ mineralization in the mixed stand and the Korean pine plantation occurred in the 16th month, June 2010, whereas the process of $\mathrm{N}$ immobilization in the oak stand was sustained until October 2010. Although the oak stand had a longer $\mathrm{N}$ immobilization phase, it showed a higher rate of $\mathrm{N}$ mineralization in the second autumn, and the percent of $\mathrm{N}$ remaining in the 
leaf litter in the oak stand was similar to that in the other stands in the 24th month. Changes in the percent of $\mathrm{N}$ remaining in the oak leaf litter was significantly different from that of Korean pine leaf litter in the oak stand $(p<0.05)$, but the other stands did not show significant differences in the percent of $\mathrm{N}$ remaining by leaf litter type (Figure $5 \mathrm{~A}-\mathrm{C}$ ).

Temporary leaching of $\mathrm{P}$ was shown at the beginning of the study, and then a process of $\mathrm{P}$ immobilization started within two months and continued until the 16th month in all study sites (Figure 5D-F). The highest $\mathrm{P}$ immobilization rate (175\%) was observed in the oak leaf litter at the mixed stand (Figure 5E). The Korean pine leaf litter had the lowest $\mathrm{P}$ immobilization percentage in all stand types. Korean pine leaf litter showed the lowest percent of $\mathrm{P}$ remaining among leaf litter types in all study sites, indicating the greatest leaf litter $\mathrm{P}$ decomposition, and oak leaf litter showed the highest percent of $\mathrm{P}$ remaining $(p<0.05)$. Percent of $\mathrm{P}$ remaining in the leaf litter in the 24th month was $59-79 \%$ in the oak stand, $77-116 \%$ in the mixed stand, and $73-100 \%$ in the Korean pine plantation. The oak stand showed the greatest $\mathrm{P}$ mineralization among the stand types. The percent of $\mathrm{P}$ remaining in the Korean pine leaf litter was lower in the oak stand than in the other stands $(p=0.018)$.

The changes in leaf litter $\mathrm{N}$ and $\mathrm{P}$ had a polynomial correlation with leaf litter $\mathrm{C}$ (Figure 6, Table 4). The relationship among leaf litter N, P, and C differed among the leaf litter types. The leaf litter $\mathrm{N}$ amount relative to leaf litter $\mathrm{C}$ loss was significantly different in the order Korean pine leaf litter $^{\mathrm{b}}<$ mixed leaf litter ${ }^{\mathrm{ab}}<$ Mongolian oak leaf litter ${ }^{\mathrm{a}}$ (Figure 6A-C; $p<0.001$ ). The inflection points between $\mathrm{N}$ immobilization and mineralization differed by stand type $(p<0.05)$. The maximum amount of leaf litter $\mathrm{N}$ peaked when the total amount of $\mathrm{C}$ ranged from $5 \mathrm{~g}$ to $6 \mathrm{~g}$, which was interpreted to be $50-60 \%$ of the initial leaf litter $\mathrm{C}$ amount, in the mixed stand and the Korean pine plantation (Figure 5B,C) and $4 \mathrm{~g}$ of $\mathrm{C}$ in the oak stand (Figure 6A). After 24 months of the experiment, leaf litter $\mathrm{C}: \mathrm{N}$ ranged from 25 to 46 . Leaf litter $\mathrm{C}: \mathrm{N}$ was not significantly different among stand types, but differed among the leaf litter types as Korean pine leaf litter had significantly higher $\mathrm{C}: \mathrm{N}$ than the other litter types $(p<0.001)$.

Korean pine leaf litter had the greatest leaf litter P content among leaf litter types. The amount of leaf litter $\mathrm{P}$ in the Mongolian oak leaf litter was significantly smaller than that in the mixed leaf litter and Korean pine leaf litter until the remaining $\mathrm{C}$ reached $4 \mathrm{~g}$ in all the stand types. The amount of leaf litter $\mathrm{P}$ became similar among all leaf litter types in the mixed stand and the Korean pine plantation after remaining $\mathrm{C}$ was less than $4 \mathrm{~g}$ (Figure 6E,F). Similar amounts of $\mathrm{C}(4-5 \mathrm{~g})$ were observed at the inflection point of $\mathrm{P}$ changes in all stand types (Figure $6 \mathrm{D}-\mathrm{F} ; p<0.05$ ). The Mongolian oak stand had significantly higher leaf litter C:P of 476 than the Korean pine plantation of 383 after 24 months $(p=0.019)$. The Mongolian oak stand had significantly higher leaf litter N:P of 14 than the other two sites of $c a .13$ $(p<0.05)$. Three litter types showed significant difference in leaf litter N:P in 24 months in the order Korean pine leaf litter ${ }^{\mathrm{c}}<$ mixed leaf litter ${ }^{\mathrm{b}}<$ Mongolian oak leaf litter ${ }^{\mathrm{a}}(p<0.05)$. 
Table 4. The relationship between amount of $\mathrm{C}, \mathrm{N}$ and $\mathrm{P}$ in each decomposing leaf litter type as described by polynomial regression.

\begin{tabular}{ccccc}
\hline Forest type & Leaf litter type & Regression & $\boldsymbol{R}^{\mathbf{2}}$ & $\boldsymbol{P}$-value \\
\hline \multirow{3}{*}{ Oak stand } & Mongolian oak & $\mathrm{N}=-0.0006 \mathrm{C}^{2}+0.0034 \mathrm{C}+0.0924$ & 0.6046 & 0.156 \\
& Mixed leaf litter & $\mathrm{P}=-0.0001 \mathrm{C}^{2}+0.0006 \mathrm{C}+0.0010$ & 0.7871 & 0.045 \\
& & $\mathrm{~N}=-0.0011 \mathrm{C}^{2}+0.009 \mathrm{C}+0.0643$ & 0.9198 & 0.006 \\
& Korean pine & $\mathrm{P}=-0.0001 \mathrm{C}^{2}+0.0009 \mathrm{C}+0.0009$ & 0.8509 & 0.022 \\
& & $\mathrm{~N}=-0.0012 \mathrm{C}^{2}+0.0104 \mathrm{C}+0.0503$ & 0.7944 & 0.042 \\
& Mongolian oak & $\mathrm{P}=-0.00003 \mathrm{C}^{2}+0.0003 \mathrm{C}+0.0024$ & 0.3239 & 0.457 \\
\hline \multirow{3}{*}{ Mixed stand } & $\mathrm{N}=-0.0016 \mathrm{C}^{2}+0.0145 \mathrm{C}+0.0606$ & 0.9046 & 0.009 \\
& Mixed leaf litter & $\mathrm{P}=-0.0001 \mathrm{C}^{2}+0.001 \mathrm{C}+0.0007$ & 0.8408 & 0.025 \\
& & $\mathrm{~N}=-0.0012 \mathrm{C}^{2}+0.012 \mathrm{C}+0.0508$ & 0.8081 & 0.037 \\
& Korean pine & $\mathrm{P}=-0.0001 \mathrm{C}^{2}+0.0008 \mathrm{C}+0.0012$ & 0.8119 & 0.035 \\
& & $\mathrm{~N}=-0.0019 \mathrm{C}^{2}+0.0203 \mathrm{C}+0.017$ & 0.8809 & 0.014 \\
& Mongolian oak & $\mathrm{P}=-0.0001 \mathrm{C}^{2}+0.001 \mathrm{C}+0.0004$ & 0.8722 & 0.016 \\
\hline \multirow{3}{*}{ Korean pine } & Mixed leaf litter & $\mathrm{N}=-0.0011 \mathrm{C}^{2}+0.0108 \mathrm{C}+0.0603$ & 0.5020 & 0.248 \\
& & $\mathrm{~N}=-0.0017 \mathrm{C}^{2}+0.017 \mathrm{C}+0.0368$ & 0.9258 & 0.006 \\
& & $\mathrm{P}=-0.0001 \mathrm{C}^{2}+0.0009 \mathrm{C}+0.001$ & 0.7812 & 0.048 \\
& \multirow{2}{*}{ Korean pine } & $\mathrm{N}=-0.0017 \mathrm{C}^{2}+0.018 \mathrm{C}+0.0233$ & 0.7957 & 0.042 \\
& & $P=-0.0001 \mathrm{C}^{2}+0.0009 \mathrm{C}+0.0009$ & 0.6936 & 0.094 \\
\hline
\end{tabular}

Figure 6. Changes in the total $\mathrm{N}((\mathbf{A}),(\mathbf{B}),(\mathbf{C}))$ and $\mathrm{P}((\mathbf{D}),(\mathbf{E}),(\mathbf{F}))$ relative to total $\mathrm{C}$ for Mongolian oak leaf litter, Korean pine leaf litter and mixed leaf litter in (A), (D) the oak stand, (B), (E) the mixed stand, and $(\mathbf{C}),(\mathbf{F})$ the Korean pine plantation.
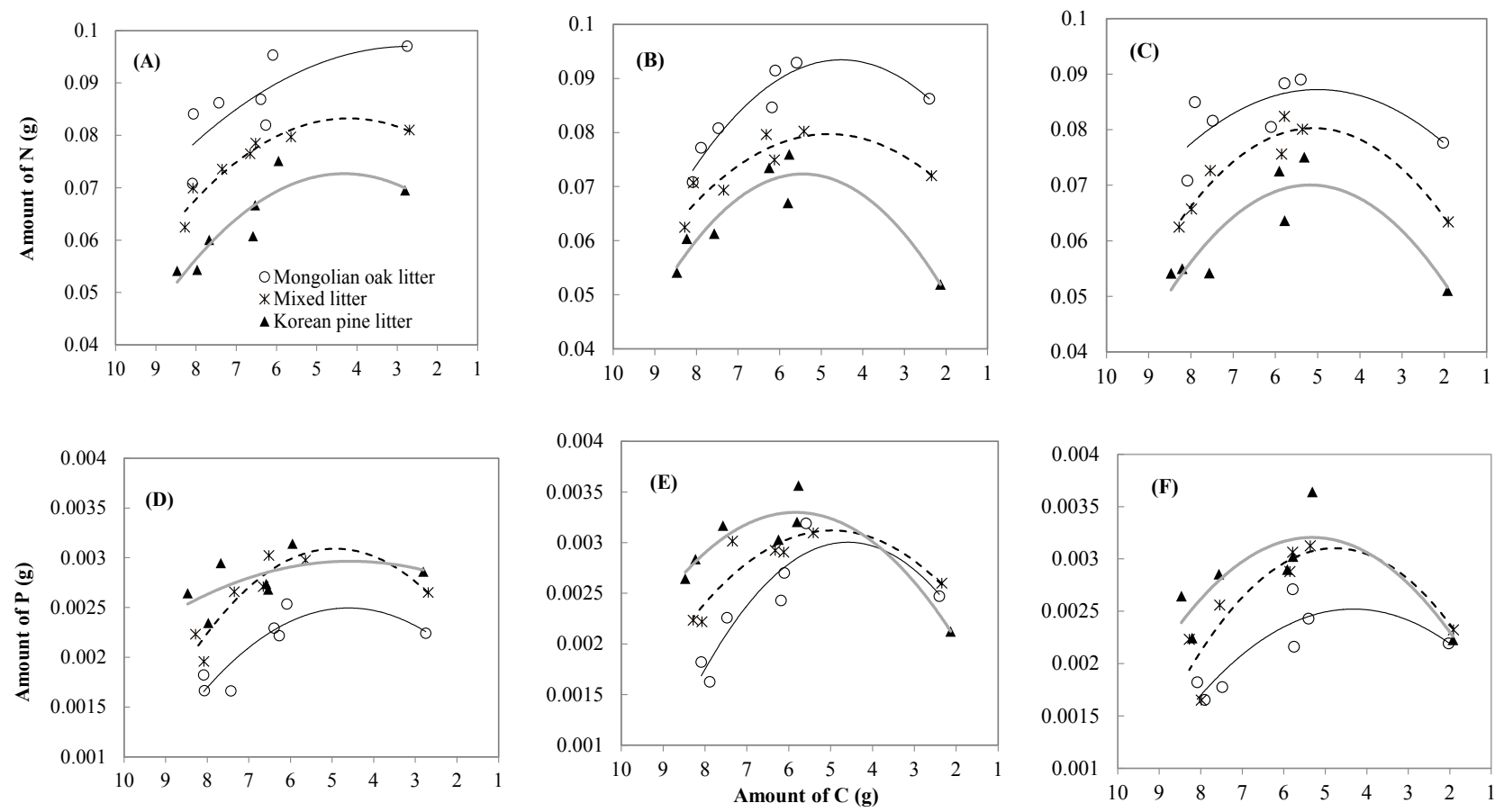


\section{Discussion}

\subsection{Seasonal Leaf litter Decomposition Patterns}

Seasonal weather changes have a large effect on leaf litter breakdown in temperate deciduous forests, especially when abundant rainfall and high summer temperatures contribute to a substantial leaf litter mass loss [32]. The majority of leaf litter decomposition in all study sites occurred from June to August, although the decomposition rates differed among the stand types. The seasonal effect on the decomposition rate of Quercus leaf litters in a temperate deciduous forest was also reported in Lee et al. [33]: the majority of leaf litter mass loss occurred in the summer, and little mass loss was detected from February to April.

In this study, the percent mass of the Korean pine leaf litter remaining after 24 months was 40-50\%, which was similar to the 51.6\% in 26 months reported in the Gwangneung Experimental Forest, in the same province as our study sites [30]. On Mt. Gyebang, which is north of Mt. Taehwa and has lower temperatures, the percent mass of leaf litter remaining after 24 months was $c a$. 52\% [34]. The percent average leaf litter mass remaining after 24 months was 55-60\% for Korean pine leaf litter in Jilin Province, northeast China, which has a higher latitude than Mt. Taehwa [19]. About 50\% of the leaf litter was decomposed during the initial two years, and the decomposition rate lowered slightly as the latitude increased, showing that temperature was a determining factor for leaf litter decomposition rate: a hotter humid summer corresponds to faster leaf litter decomposition in temperate deciduous forests in NE Asia [35].

All study sites had the same soil texture (loam) and similar soil temperatures. Soil moisture contents were similar in the summer and different in spring and autumn. The oak stand and mixed stand were on a north slope, and the Korean pine plantation was mostly on a south slope, which explained why the lowest soil moisture content was found in the Korean pine plantation in the dry seasons of spring and autumn [36,37]. Leaf litter decomposition rate generally increases with soil moisture content [38]. However, our study sites had similar decomposition rates after 24 months, indicating that the soil moisture content in summer was the key determinant of leaf litter decomposition and confirming the importance of summer weather in leaf litter decomposition [39].

\subsection{Mixed Leaf Litter Effect}

The leaf litter decomposition rate of broadleaved species is generally higher than that of conifers [40,41]. However, the decomposition rates of Mongolian oak leaves and Korean pine needles in the same stand were not different in this study. Mongolian oak leaves have thick hard blades and low nutrient content compared with other oak species, retarding the leaf litter decomposition rate [34] and contributing to the similar decomposition rates of the two species.

The mixed leaf litter of Korean pine and Mongolian oak showed no mixed litter effect on leaf litter decomposition, indicating that the interaction strength between the leaf litters of the two species was weak. The leaf litter decomposition rate of the mixed leaf litter could therefore be predicted from the decomposition rate of each individual species [15]. Mixed leaf litter could have a higher decomposition rate than a single-species leaf litter because nutrient exchange among leaf litters of different species through microbes could enhance the nutrient condition of low-quality leaf litters, accelerating the 
decomposition rate [27,42]. At the beginning, Mongolian oak leaves contained more N, and Korean pine needles had more P (Figure 6). We could observe more physical breakdown of the Mongolian oak leaf litter in the mixed leaf litter. However, contrary to our expectations that transport of nutrients between the Mongolian oak leaf litter and the Korean pine leaf litter would induce complementary interactions and a synergistic effect, an actual mixed effect on the remaining mass was not detected within 24 months, suggesting that synergistic effects of mixed leaf litters of contrasting qualities is questionable [29,43]. Moreover, the seasonal climate was a primary control on the leaf litter decomposition pattern, making species difference less powerful in leaf litter decomposition in a temperate deciduous forest [44]. However, the possibility that an additive effect is temporary and switches to a non-additive effect as decomposition progresses still exists because the non-additive effect of mixed leaf litters for mass loss could be time dependent [45].

\subsection{Leaf Litter Nutrient Dynamics}

After two years of experiments, only $10-20 \%$ of net $\mathrm{N}$ mineralization was detected due to the immobilization process in the initial decomposition period, which lasted longer than one year. Nutrients in decaying foliar leaf litter temporarily increase due to nutrient immobilization by microbes in the initial mass loss process. The leaf litter $\mathrm{N}$ and $\mathrm{P}$ immobilization phase prolonged more than 14 months in this study, which was similar to the $\mathrm{N}$ and $\mathrm{P}$ immobilization phase of more than 15 months in the foliar leaf litter decomposition of oak and Korean pine in a broadleaf-Korean pine mixed forest in NE China [19].

Different leaf litter types had a similar period for the immobilization and mineralization of $\mathrm{N}$ and $\mathrm{P}$ to diminishing $\mathrm{C}$ as well as similar leaf litter decomposition rates at the same stand. Net $\mathrm{N}$ mineralization rates of leaf litter are greatly influenced by the site conditions rather than leaf litter species, causing the same species to show different mineralization rates depending on the site [46].

Although soil $\mathrm{N}$ is an important determinant in leaf litter decay, soil $\mathrm{P}$ becomes a stronger control for leaf litter decay when it is limited under abundant soil N [47]. Seasonal P dynamics are more variable than $\mathrm{N}$ in leaf litter decomposition [48]. High precipitation in the summer promotes the movement of phosphate in the soil, inducing seasonal changes in the distribution of soil phosphate [33]. Thus, the proportions of $\mathrm{P}$ with other nutrients, such as $\mathrm{C}: \mathrm{P}$ and $\mathrm{N}: \mathrm{P}$, as well as the concentration of $\mathrm{P}$ itself, were major regulators that could inhibit or further decay rates by providing a balanced nutritional pool for decomposers $[28,49]$. Seasonal changes in soil N:P in the oak stand were related to changes in available $\mathrm{P}$ content. The lowest soil $\mathrm{P}_{2} \mathrm{O}_{5}$ and spatial and seasonal variances of soil $\mathrm{P}_{2} \mathrm{O}_{5}$ (Table 2) and N:P (Figure 2) might contribute to a fluctuation of nutrient supply that could explain the lowest leaf litter decomposition rate prior to the second summer and the different patterns of immobilization and mineralization of $\mathrm{N}$ and $\mathrm{P}$ in the oak stand compared with the other stands. Therefore, leaf litter nutrient dynamics were more affected by site conditions than by leaf litter types, suggesting that leaf litter decomposition and leaf litter nutrient dynamics patterns between a secondary forest and an adjacent plantation would not be much different if the site condition and stand age were similar, due to the overwhelming seasonal climatic effect on leaf litter decomposition in temperate deciduous forests.

Oak leaf litter showed the smallest $\mathrm{P}$ content among leaf litter types, which might be related to the occurrence of least soil $\mathrm{P}_{2} \mathrm{O}_{5}$ in the oak stand. The Korean pine plantation had the lowest soil TP, but it had the highest soil $\mathrm{P}_{2} \mathrm{O}_{5}$ among the stand types, and the Korean pine leaf litter had the greatest leaf litter 
$\mathrm{P}$ content and mineralization rate, suggesting that after 40 years of occupation of a Korean pine plantation might increase soil $\mathrm{P}_{2} \mathrm{O}_{5}$ [50]. Lee et al. [33] reported that rapid $\mathrm{P}$ cycling in black locust communities resulted in increased membrane phosphate in soil compared with adjacent Mongolian oak communities. Although the effects of species composition might be less powerful than climate on leaf litter decomposition in temperate deciduous forests, effects of species change on detailed leaf litter decomposition process, such as leaf litter nutrient dynamics and soil nutrients, can be expected [10]. We could suggest different leaf litter decomposition patterns relevant to leaf litter $\mathrm{N}$ and $\mathrm{P}$ dynamics and soil properties between the Korean pine plantation and the oak stand. We expect that further studies on decomposer communities would clarify the decomposition mechanism in temperate deciduous forests.

\section{Conclusions}

This study compared the leaf litter decomposition patterns and nutrient dynamics between a Korean pine plantation and an adjacent native Mongolian oak-dominant broadleaved temperate forest. Seasonal climate, especially hot and humid summer weather, was a more powerful determinant in leaf litter decomposition patterns than leaf litter types, resulting in no mixed leaf litter effect on leaf litter decomposition. However, we did find effects of the changes in dominant species on leaf litter nutrient dynamics and soil nutrients. The conversion of natural forests into plantations may have long-term effects on nutrients available in the soil, eventually modifying soil nutrient budgets.

\section{Acknowledgments}

This study was supported by the Korea Forest Service (Project No. S111214L020130 and S211314L020100). We thank all the participants in the field survey and data processing. We thank the Seoul National University Forest for providing access to the study sites and weather data. We acknowledge the Research Institute of Agriculture and Life Sciences, Seoul National University for grammar assistance and anonymous reviewers for their valuable comments.

\section{Author Contributions}

Jaeeun Sohng and Pil Sun Park conceived and designed the experiments. Jaeeun Sohng carried out field work, data analysis and prepared the manuscript. Ah Reum Han, Mi-Ae Jeong, and Yunmi Park contributed to field work and data analysis. Byung Bae Park contributed to the chemical analysis of soil and leaf litter. Pil Sun Park supervised the study, did additional data analysis and reviewed and edited the work.

\section{Conflicts of Interest}

The authors declare no conflict of interest.

\section{References}

1. Gosz, J. Organic matter and nutrient dynamics of the forest and forest floor in the Hubbard Brook Forest. Oecologia 1976, 22, 305-320. 
2. Meentemeyer, V. An approach to the biometereology of decomposer organisms. Int. J. Biometeorol. 1978, 22, 94-111.

3. Mudrick, D.A.; Hoosein, M.; Ray, R.H.J.; Townsend, E.C. Decomposition of leaf litter in an Appalachian forest: Effects of leaf species, aspect, slope position and time. For. Ecol. Manage. 1994, 68, 231-250.

4. Sariyildiz, T.; Anderson, J.M.; Kucuk, M. Effects of tree species and topography on soil chemistry, leaf litter quality, and decomposition in Northeast Turkey. Soil Biol. Biochem. 2005, 37, 1695-1706.

5. Fogel, R.; Cromack, K.J. Effect of habitat and substrate quality on Douglas-fir leaf litter decomposition in western Oregon. Can. J. Bot. 1977, 55, 1632-1640.

6. Valachovic, Y.S.; Caldwell, B.A.; Cromack, K. Jr.; Griffiths, R.P. Leaf litter chemistry controls on decomposition of Pacific Northwest trees and woody shrubs. Can. J. For. Res. 2004, 34, 2131-2147.

7. Prescott, C.E. Influence of forest floor type on rates of leaf litter decomposition in microcosms. Soil Biol. Biochem. 1996, 28, 1319-1325.

8. Zhou, G.; Guan, L.; Wei, X.; Tang, X.; Liu, S.; Liu, J.; Zhang, D.; Yan, J. Factors influencing leaf litter decomposition: An intersite decomposition experiment across China. Plant Soil 2008, 311, $61-72$.

9. Rouifed, S.; Handa, I.T.; David, J.-F.; Hättenschwiler, S. The importance of biotic factors in predicting global change effects on decomposition of temperate forest leaf litter. Oecologia 2010, $163,247-256$.

10. Aponte, C.; García, L.V.; Marañón, T. Tree species effect on leaf litter decomposition and nutrient release in Mediterranean oak forests changes over time. Ecosystems 2012, 15, 1204-1218.

11. Madritch, M.D.; Cardinale, B.J. Impacts of tree species diversity on leaf litter decomposition in northern temperate forests of Wisconsin, USA: A multi-site experiment along a latitudinal gradient Plant Soil 2007, 292, 147-159.

12. Wang, Q.; Wang, S.; Xu, G.; Fan, B. Conversion of secondary broadleaved forest into Chinese fir plantation alters leaf litter production and potential nutrient returns. Plant Ecol. 2010, 209, 269-278.

13. Lian, Y.; Zhang, Q. Conversion of a natural broad-leafed evergreen forest into pure and mixed plantation forests in a subtropical area: Effects on nutrient cycling. Can. J. For. Res. 1998, 28, 1518-1529.

14. Rothe, A.; Binkley, D. Nutritional interactions in mixed species forests: A synthesis. Can. J. For. Res. 2001, 31, 1855-1870.

15. Hoorens, B.; Aerts, R.; Stroetenga, M. Does initial leaf litter chemistry explain leaf litter mixture effects on decomposition? Oecologia 2003, 137, 578-586.

16. Gartner, T.B.; Cardon, Z.G. Decomposition dynamics in mixed-species leaf litter. Oikos 2004, 104, 230-246.

17. Gholz, H.; Wedin, D.; Smitherman, S.; Harmon, M.; Parton, W. Long-term dynamics of pine and hardwood leaf litter in contrasting environments: Toward a global model of decomposition. Glob. Change Biol. 2000, 6, 751-765. 
18. Laganiere, J.; Pare, D.; Bradley, R.L. How does a tree species influence leaf litter decomposition? Separating the relative contribution of leaf litter quality, leaf litter mixing, and forest floor conditions. Can. J. For. Res. 2010, 40, 465-475.

19. Li, X.; Han, S.; Zhang, Y. Foliar decomposition in a broadleaf-mixed Korean pine, Pinus koraiensis Sieb. et Zucc. plantation forest, the impact of initial leaf litter quality and the decomposition of three kinds of organic matter fraction on mass loss and nutrient release rates. Plant Soil 2007, 295, 151-167.

20. Korea Forest Service. Statistical Yearbook of Forestry; Korea Forest Service: Daejeon, Korea, 2011.

21. Zhang, P.; Shao, G.; Zhao, G.; Le Master, D.C.; Parker, G.R.; Dunning, J.B. Jr.; Li, Q. China's forest policy for the 21st century. Science 2000, 288, 2135-2136.

22. Weather information. Available online: http://www.kma.go.kr/weather/climate/average_30years. jsp (accessed on 3 October 2013).

23. Buol, S.W.; Southar, R.J.; Graham, R.C.; McDaniel, P.A. Soil Genesis and Classification; 5th ed.; Iowa State Press: Iowa, IA, USA, 2003.

24. Miller, W.P.; Miller, D.M. A micro - pipette method for soil mechanical analysis. Commun. Soil Sci. Plan. 1987, 18, 1-15.

25. Konen, M.E.; Jacobs, P.M.; Burras, C.L.; Talaga, B.J.; Mason, J.A. Equations for predicting soil organic carbon using Loss-on-Ignition for North Central U.S. soils. Soil Sci. Soc. Am. J. 2002, 66, 1878-1881.

26. Sumner, M.E.; Miller, W.P. Cation exchange capacity, and exchange coefficients. In Methods of Soil Analysis, Part 3. Chemical methods. Soil Science of Society of America Book Series no. 5; 3rd ed.; Sparks, D.L., Ed.; Soil Science Society of America: Madison, WI, USA, 1996; pp. 1201-1229.

27. Wardle, D.A.; Bonner, K.I.; Nicholson, K.S. Biodiversity and plant leaf litter: Experimental evidence which does not support the view that enhanced species richness improves ecosystem function. Oikos 1997, 79, 247-258.

28. Xu, X.; Hirata, E. Decomposition patterns of leaf litter of seven common canopy species in a subtropical forest: N and P dynamics. Plant Soil 2005, 273, 279-289.

29. Bonanomi, G.; Incerti, G.; Antignani, V.; Capodilupo, M.; Mazzoleni, S. Decomposition and nutrient dynamics in mixed leaf litter of Mediterranean species. Plant Soil 2010, 331, 481-496.

30. You, Y.H.; Namgung, J.; Lee, Y.Y.; Kim, J.H.; Lee, J.Y.; Mun, H.T. Mass loss and nutrients dynamics during the leaf litter decomposition in Kwangnung experimental forest. Jour. Korean For. Soc. 2000, 89, 41-48.

31. Olson, J.S. Energy stores and the balance of producers and decomposers in ecological systems. Ecology 1963, 44, 322-331.

32. Anaya, C.A.; Jaramillo, V.J.; Martínez-yrízar, A.; García-oliva, F. Large rainfall pulses control leaf litter decomposition in a tropical dry forest: Evidence from an 8-year study. Ecosystems 2012, 15; $652-663$.

33. Lee, Y.C.; Nam, J.M.; Kim, J.G. The influence of black locust, Robinia pseudoacacia. flower and leaf fall on soil phosphate. Plant Soil 2011, 341, 269-277. 
34. Lee, I.K.; Lim, J.H.; Kim, C.S.; Kim, Y.K. Nutrient dynamics in decomposing leaf litter and leaf litter production at the long-term ecological research site in Mt. Gyebangsan. J. Ecol. Field Biol. 2006, 29, 585-591.

35. Zhang, D.; Hui, D.; Luo, Y.; Zhou, G. Rates of leaf litter decomposition in terrestrial ecosystems: Global patterns and controlling factors. J. Plant Ecol. 2008, 1, 85-93.

36. Han, A.R.; Lee, S.K.; Suh, G.U.; Park, Y.; Park, P.S. Wind and topography influence the crown growth of Picea jezoensis in a subalpine forest on Mt. Deogyu, Korea. Agric. For. Meteorol. 2012, 166-167, 207-214.

37. Hinckley, E-L. S.; Ebel, B.A.; Barnes, R.T.; Anderson, R.S.; Williams, M.W.; Anderson, S.P. Aspect control of water movement on hillslopes near the rain-snow transition of the Colorado Front Range. Hydrolo. Proc. 2014, 28, 74-85.

38. Wang, S.; Ruan, H.; Han, Y. Effects of microclimate, leaf litter type, and mesh size on leaf litter decomposition along an elevation gradient in the Wuyi Mountains, China. Ecol. Res. 2010, 25, 1113-1120.

39. Austin, A.T.; Vitousek, P.M. Precipitation, decomposition and leaf litter decomposability of Metrosideros polymorpha in native forests on Hawaii. J. Ecol. 2000, 88, 129-138.

40. Mun, H.T.; Joo, H.T. Leaf litter production and decomposition in the Quercus acutissima and Pinus rigida forests. Korean J. Ecol. 1994, 17, 345-353.

41. Hisabae, M.; Sone, S.; Inoue, M. Breakdown and macrointervebrate colonization of needle and leaf litter in conifer plantation streams in Shikoku, southwestern Japan. J. For. Res. 2011, 16, 108-115.

42. Bardgett, R.D.; Shine, A. Linkages between plant leaf litter diversity, soil microbial biomass and ecosystem function in temperate grasslands. Soil Biol Biochem 1999, 31, 317-321.

43. De Marco, A.; Meola, A.; Maisto, G.; Giordano, M.; De Santo, A.V. Non-additive effects of leaf litter mixtures on decomposition of leaf litters in a Mediterranean maquis. Plant Soil 2011, 344, 305-317.

44. García-Palacios, P.; Maestre, F.T.; Kattge, J.; Wall, D.H. Climate and leaf litter quality differently modulate the effects of soil fauna on leaf litter decomposition across biomes. Ecol. Lett. 2013, 16, 1045-1053.

45. Chapman, S.K.; Newman, G.S.; Hart, S.C.; Schweitzer, J.A.; Koch, G.W. Leaf litter mixtures alter microbial community development: mechanisms for non-additive effects in leaf litter decomposition. PLoS One 2013, 8, doi:10.1371/journal.pone.0062671.

46. Prescott, C.E.; Vesterdal, L.; Pratt, J.; Venner, K.H.; Montigny, L.M.D. Trofymow, J.A. Nutrient concentrations and nitrogen mineralization in forest floors of single species conifer plantations in coastal British Columbia. Can. J. For. Res. 2000, 30, 1341-1352.

47. Hobbie, S.E.; Vitousek, P.M. Nutrient limitation of decomposition in Hawaiian forests. Ecology 2000, 81, 1867-1877.

48. Aerts, R.; Callaghan, T.V.; Dorrepaal, E.; van Logtestijn, R.S.P.; Cornelissen, J.H.C. Seasonal climate manipulations have only minor effects on leaf litter decomposition rates and $\mathrm{N}$ dynamics but strong effects on leaf litter P dynamics of sub-arctic bog species. Oecologia 2012, 170, 809-819. 
49. Moore, T.R.; Trofymow, J.A.; Prescott, C.E.; Titus, B.D.; Group, C.W. Nature and nurture in the dynamics of C, N and P during leaf litter decomposition in Canadian forests. Plant Soil 2011, 339, 163-175.

50. Celi, L.; Cerli, C.; Turner, B.L.; Santoni, S.; Bonifacio, E. Biogeochemical cycling of soil phosphorus during natural revegetation of Pinus sylvestris on disused sand quarries in Northwestern Russia. Plant Soil 2013, 367, 121-134.

(C) 2014 by the authors; licensee MDPI, Basel, Switzerland. This article is an open access article distributed under the terms and conditions of the Creative Commons Attribution license (http://creativecommons.org/licenses/by/4.0/). 